\title{
AN ANALYSIS ON VERB COLLOCATIONS OF 'EXCITED': CORPUS-BASED RESEARCH
}

\author{
Rex Stardy \\ Universitas Bunda Mulia \\ rexstardy@yahoo.com
}

\begin{abstract}
In learning English, one main problem that learners often encounter is learning vocabulary. Learners cannot use English to communicate if they do not have enough words or vocabulary to convey what they want to say. That is why, learning vocabulary is important. However, it is not always easy to learn vocabulary. Learning vocabulary can be troublesome. One type of vocabulary which is confusing for learners to learn is adjectives, especially verbal adjectives. Verbal adjectives are adjectives which are derived from verbs. These adjectives usually have -ed and -ing ending. Some examples are 'bored', 'boring', 'confused', 'confusing', 'excited', 'exciting', etc. These adjectives are often confusing for learners of English. Based on this problem, the writer decided to conduct research about this adjective. However, the writer only wants to analize and discuss the adjectives that end with-ed. The specific word that is going to be analized is 'excited'. Since this research is corpus based research, the research will focus on the verbs that collocate with the adjective 'excited'. The writer will see how many verbs that frequently collocate with 'excited'. After that, the writer will see the differences between those verbs. Finally, the writer will compare the results of the COCA and the results of the students' test. In learning English, one main problem that learners often encounter is learning vocabulary. Learners cannot use English to communicate if they do not have enough words or vocabulary to convey what they want to say. That is why, learning vocabulary is important. However, it is not always easy to learn vocabulary. Learning vocabulary can be troublesome. One type of vocabulary which is confusing for learners to learn is adjectives, especially verbal adjectives. Verbal adjectives are adjectives which are derived from verbs. These adjectives usually have -ed and -ing ending. Some examples are 'bored', 'boring', 'confused', 'confusing', 'excited', 'exciting', etc. These adjectives are often confusing for learners of English. Based on this problem, the writer decided to conduct research about this adjective. However, the writer only wants to analyze and discuss the adjectives that end with-ed. The specific word that is going to be analized is 'excited'. Since this research is corpus based research, the research will focus on the verbs that collocate with the adjective 'excited'. The writer will see how many verbs that frequently collocate with 'excited'. After that, the writer will see the differences between those verbs. Finally, the writer will compare the results of the COCA and the results of the students' test.
\end{abstract}

Keywords: corpus, verb collocation, excited

\begin{abstract}
ABSTRAK
Dalam mempelajari Bahasa Inggris, salah satu masalah utama yang sering dihadapi oleh para pelajar adalah mempelajari perbendaharaan kata. Para pelajar tidak dapat menggunakan Bahasa Inggris jika mereka tidak memiliki cukup perbendaharaan kata untuk menyampaikan apa yang ingin mereka sampaikan. Oleh karena itu, mempelajari perbendaharaan kata sangatlah penting. Akan tetapi, belajar perbendaharaan kata tidaklah selalu mudah. Belajar perbendaharaan kata bisa menyulitkan. Salah satu jenis perbendaharaan kata yang menbingungkan bagi pelajar adalah kata sifat (adjektifa), terutama adjektifa kata kerja (verbal adjektifa). Verbal adjektifa adalah adjektifa yang berasal dari kata kerja (verba). Adjektifa ini biasanya memiliki akhiran -ed dan -ing. Beberapa contohnya adalah 'bored', 'boring', 'confused', 'confusing', 'excited', 'exciting', dsb. Adjektifa ini sering membingungkan para pelajar Bahasa Inggris. Berdasarkan masalah ini, penulis memutuskan untuk mengadakan penelitian mengenai adjektifa ini. Akan tetapi, penulis hanya akan menganalisa dan membahas adjektifa yang berakhiran dengan -ed. Kata yang akan dianalisa adalah 'excited'. Karena ini merupakan penelitian berdasarkan korpus, penelitian ini akanberfokus pada kata kerja (verba) yang berkolokasi dengan adjektifa 'excited'. Penulis akan melihat ada berapa banyak verba yang sering berkolokasi dengan 'excited'. Kemudian, penulis akan melihat perbedaan diantara kata verba tersebut. Terakhir, penulis akan membandingkan hasil dari COCA dengan hasil dari tes para mahasiswa.
\end{abstract}

Kata Kunci: korpus, kolokasi kata kerja, excited 


\section{INTRODUCTION}

\section{Background}

English as an international language has an important role in people's life. English has been used widely by people all over the world as a mean of communication. Considering the important role of English, many people all over the world begin to learn English in order to be able to survive in the competition. In learning English, there are four basic skills thatare needed to be learnt. These four skills are: speaking, listening, reading and writing. Besides these four skills, a person needs to learn other knowledge of English. Some of these knowledge are: grammar, vocabulary and pronunciation. Understanding these knowledge can help a person to accelerate the process in learning English. For example, when a person wants to learn speaking skill, he can learn it faster if he has fluent pronunciation, good grammar and sufficient knowledge of vocabulary. That is why, learners of English must be competent in both the skills and knowledge of English.

In learning English, one main problem that learners often encounter is learning vocabulary. Learners cannot use English to communicate if they do not have enough words or vocabulary to convey what they want to say. That is why, learning vocabulary is important. However, it is not always easy to learn vocabulary. Learning vocabulary can be troublesome. One type of vocabulary which is confusing for learners to learn is adjectives, especially verbal adjectives. Verbal adjectives are adjectives which are derived from verbs. These adjectives usually have -ed and -ing ending. Some examples are 'bored', 'boring', 'confused', 'confusing', 'excited', 'exciting', etc. These adjectives are often confusing for learners of English.

In order to handle this problem, learners usually consult their dictionaries to look up for the right adjective. In a dictionary, learners can find the definition of the adjective that they are looking for. They can also find the collocation that comes with the adjective. However, there is no context of collocation in the dictionary. Meanwhile, it is necessary to know the context in order to use the collocation correctly. Therefore, understanding the context can help learners in using the collocations. For example, the noun 'homework' can collocate with verbs 'do', 'finish', and 'complete'. The context for collocation 'finish homework' and 'complete homework' always related to school. Meanwhile, 'do homework' is related to context other than school. So, once again, we can say that context is important for the right usage of collocation.

Looking back to the problem of this research, about verbal adjectives ending with -ed and -ing, the writer decided to limit the scope of this research. The writer only wants to analize and discuss the adjectives that end with -ed. The specific word that is going to be analized is 'excited'. Since this research is corpus based research, the research will focus on the verbs that collocate with the adjective 'excited'. The writer will see how many verbs that frequently collocate with 'excited'. The reason why the writer uses COCA as a tool to analize this problem is because in COCA there are millions of examples of collocations produced by native speakers of English. By using COCA, the writer can see how many verbs that collocate with the adjective 'excited' and in what contexts these verbs occur.

\section{Research Questions}

Considering the problem about verb collocation of adjective 'excited' mentioned in the research background, there are three research questions that the writer wants to find out. The research questions are as follows:

1) What are the most frequent verb colocations of 'excited' shown in COCA?

2) What are the differences and similarities between those verb collocations?

3 ) Is there any differences between the result of the COCA and the the result of the students' test?

\section{Objectives of the Study}

Based on the research questions above, there are some objectives that the writer wants to achieve. These objectives are:

1) To find out what the most frequent verbs which collocate with 'excited' are.

2) To find out what the differences are between those verb collocations. 
3) To find out if there is any difference between the result of the COCA and the result of the students' test.

\section{Scope and Limitation of the Study}

Since there are so many programs or softwares that can be used to analize corpus, either online or offline, the writer decides to use only one program. The program that is used in this research is COCA (Corpus of Contemporary American English). The reason why the writers uses COCA is because it consists of more than 520 million words which are recorded from $1990-2015$. It is also always updated every year. So, the amount of the words in COCA data base keeps increasing every year.

Not all verbs that collocate with 'excited' will be analized. This research will only focus on the verbs that has one span (word) on the left node (the main word that we want to search). In addition, it is also searched based on the lemma (basic word) of the word.The analysis of this research, however, doesn't discuss the verb 'be' because it is the most common verb that collocates with 'excited'. This research also limits the analysis of the concordance lines to only 60 lines only.

The subjects used for this study are students of Bunda Mulia University. These students are $6^{\text {th }}$ semester students and are majoring in English. There are 18 students. The reason why the writer chooses 6th semester students is because they are taking Corpus Class in that semester. So, the writer hopes that they have better understanding in differentiating verb collocations.

\section{LITERATURE REVIEW}

\section{The Definition of Corpus}

What is corpus? According to https://en.wikipedia.org/wiki/Text_corpus, "corpus is a large and structured set of texts (nowadays usually electronically stored and processed)". According to $\mathrm{http} / / /$ language.worldofcomputing.net/linguist ics/introduction/what-is-corpus.html, corpus is "a large collection of texts. It is a body of written or spoken material upon which a linguistics analysis is based". According to https://en.oxforddictionaries.com/explore/wh at-is-a-corpus, the definition of corpus is "a collection of texts of written (or spoken) language presented in electronic form. It provides the evidence of how language is used in real situations, from which lexicographers can write accurate and meaningful dictionary entries". In addition, https://www.merriam-

webster.com/dictionary/corpus defines corpus as "a collection or body of knowledge or evidence; especially : a collection of recorded utterances used as a basis for the descriptive analysis of a language". Sinclair (1991) says that "a corpus is a collection of pieces of language text in electronic form, selected according to external criteria to represent, as far as possible, a language or language variety as a source of data for linguistic research." In addition, Thornbury (as quoted in Krishnamurthy, 2014, p. 4) states that corpus is "a collection of actuallyoccuring texts (either spoken or written), stored and accessed by means of computers, and useful for investigating language use".

\section{The Definition of Collocation}

What is the definiton of collocation? According to Crystal (as quoted in Newmark, 1988 , p. 212) collocation is the "habitual cooccurrence of individual lexical items". In addition, Larson (1984, p. 144) states that collocation is "words joined together in phrases or sentences to form semantically unified expressions". Meanwhile, other writer like Sinclair (1991, p. 171) defines collocation as "the occurance of two or more words within a short space of each other in a text". To sum up, collocation is a combination of words which are usually joined together.

Collocation can be classified into several classifications or groups. Benson, Benson, and Ilson (1997) classify collocation into two classifications. They are: lexical collocation and grammatical collocation. Lexical collocation consists of nouns, adjectives, verbs and adverbs. Meanwhile, grammatical collocation is the combination of dominant word (noun, adjective, verb) with a preposition or grammatical structure such as infinitive or clause. Here are the types of lexical collocation according to Benson, Benson, and Ilson (1997):

1) verb (creation-activation) + noun (pronoun, preposition phrase)

2) verb (eradication-nullification) + noun 
3) adjective + noun

4) noun + verb (action characteristic of a person or a thing)

5) noun + of + noun (groups / units of things)

6) adverb + adjective

7) verb + adverb

Meanwhile, Benson, Benson, and Ilson (1997) classify grammatical collocation into eight types:

1) noun + preposition

2) noun + to-infinitive

3) noun + that-clause

4) preposition + noun

5) adjective + preposition

6) adjective + to-infinitive

7) adjective + that-clause

8) 19 different verb patterns in English

Different from Benson, Benson, and Ilson (1997) who categorize collocation into two major groups, another writer, Newmark (1981) categorizes collocation into seven types:

1) verb + verbal noun

2) determiner + adjective + noun

3) adverb + adjective

4) verb + adverb or adjective

5) subject + verb

6) count noun + of + mass count

7) collective noun + count noun

\section{Corpus Linguistics}

The existence of corpora in English linguistics is very useful for both lecturers and learners because corpora can be used as an evidence for real life language use. Just like Sinclair has stated (as quoted in Krishnamurti, 2014, p. 6) that "there are many facts about language that cannot be discovered by just thinking about it, or even reading or listening very intently". In other words, it shows that learners and letcurers cannot rely on their knowledge only. That is why, in this case, corpora can be very hepful. Considering the importance of the corpora, that is why there are many concordancers (corpora programs/ softwares), either online or offline, available to be used by learners of English. Some of these concordancers are COCA (Corpus of Contemporary American English) and BNC (British National Corpus).

\section{Previous Studies}

There are several studies about corpus based research which have been done by several researchers. One of them is conducted by Yusuf (2009). In her research entitled "A Corpus-Based Linguistics Analysis on Written Corpus: Colligation of TO and FOR", she investigates about the similarity and differences of the colligations of "to" and "for" in their function as prepositions in sentences in corpus. She uses ICE (International Corpus of English) as the source of reference. She examines whether the students have applied collogations of "to" and "for" correctly in their essays. The finding of her reseach is that both "to" and "for" are mostly followed by a noun or a noun phrase in grammatical sentence.

\section{RESEARCH METHOD}

\section{Research Design}

According

to

https://www.snapsurveys.com/blog/what-isthe-difference-between-qualitative-researchand-quantitative-research/, qualitative research is "primarily exploratory research. It is used to gain an understanding of underlying reasons, opinions, and motivations. It provides insights into the problem or helps to develop ideas or hypotheses for potential quantitative research. Qualitative research is also used to uncover trends in thought and opinions, and dive deeper into the problem. Qualitative data collection methods vary using unstructured or semi-structured techniques. Some common methods include focus groups (group discussions), individual interviews, and participation/observations. The sample size is typically small, and respondents are selected to fulfill a given quota."

Meanwhile, quantitative research is "used to quantify the problem by way of generating numerical data or data that can be transformed into useable statistics. It is used to quantify attitudes, opinions, behaviors, and other defined variables - and generalize results from a larger sample population. Quantitative research uses measurable data to formulate facts and uncover patterns in research."

If we take a look at the above definition, the research that the writer is conducting now can be classified as a 
Qualitative Research. This research will not use any complex counting by using any statistical software like SPSS. The research will not be dealing with Mean or Standard Deviation. In this research, the writer will only count the amount of verbs that frequently occur with the adjective 'excited'. The writer will only describe and explain how many verbs that occur with adjective 'excited', what are the verbs and what are the similarities and differences that these verbs have.This kind of data is called descriptive data. That is why, this research can be categorized as descriptive qualitative research.

\section{Data Collection Procedures}

In this research, the writer uses two techniques in collecting the data. First, the writer observes the data. Observation in this case is different from observation which is usually conducted in action research. Observation in action research involves watching, observing, and recording a behaviour, situation or circumstances. Observation in this research means that the writer observes each of the data (verb collocation) which is shown in COCA. The writer observes what verbs that collocate with adjective 'excited', how frequent they occur, and what are the similarities and the differences between those verbs.

\section{Research Instrument}

The instrument which is used in this research is COCA (Corpus of ContemporaryAmerican English). The Corpus of Contemporary American English (COCA) is the largest freely-available corpus of English, and the only large and balanced corpus of American English. COCA is probably the most widely-used corpus of English, and it is related to many other corpora of English that has been created, which offer unparalleled insight into variation in English.

COCA is used in this research because it consists of more than 520 million words which are recorded from $1990-2015$. It is also always updated every year. So, the amount of the words in COCA data base keeps increasing every year. COCA was created by Mark Davis, a professor at Birmingham University. COCA contains a collection of authentic American English texts taken from five different registers / types. These five registers are spoken, fiction, newspaper, magazine and academis. COCA can be accessed freely in http://corpus.byu.edu/coca/ website.

\section{Data Analysis Procedures}

In this research, the procedure or technique that is used in analising the data is as follows:

1) The writer inputs the adjective 'excited' in the word / phrase box in the COCA. The writer also inputs 'verb' in the collocation box. The writer also limits the search by only inputing one node (word) in front of the adjective 'excited'. So, later, the results will only show only one verb in front of the adjective 'excited', not two verbs.

2) After the results come out, we can see that there are several verbs that collocate with 'excited'. There, we can also see the frequency of each verb. We can see which verb that has the highest and the lowest frequency. From this result, the writer can determine which top two verbs that occur frequently with adjective 'excited'.

3) After deciding the two verbs, the writer then will analise the differences and the similarities of these two verbs.

4) Then, the writer makes a collocation test for the students and distributes it to them. After collected, the writer will analize the result of the test.

5) Finally, after knowing the differences between those verbs, the writer will compare the result of COCA with the result of the students' test.

\section{FINDINGS AND DISCUSSION}

From the data taken from COCA, the writer finds that there are two verbs that frequently collocate with the word 'excited'. Those verbs are: "be" and "get". Those verbs have the highest frequency. After analizing all of the 60 concordances lines in COCA for each verb, the writer can conclude that there is indeed a difference between those two verbs.

The result is as follows: the verb "be" is usually used with adjective 'excited' when the person already has that 'excited' feeling when he says the word. For example, when 
someone says "I am excited with this party", it means that he has already felt excited when he says that sentence.

On the other hand, the verb "get" is used when someone just start to feel excited. For instance, when a person says "I get excited with the upcoming party tonight', it means that at the beginning he doesn't feel excited with the party. However, when he says that sentence, he begins to feel excited. In other words, we can say "I get excited" when we start to feel excited.

After knowing the differences between those two verbs, the writer then analizes the result of the students' test. The result of the test can be seen in the table 1 .

From the table above, we can see that questions number 1-10 have the same answers. According to COCA, the answers are 'be'. Now, let us compare it with the results from the students' answers. For questions number $1,2,4,6,8$ and 9 , most of the students have the same answers just like in COCA. The answers are 'be'. While for questions number 5, 7, and 10, most of the students answer with 'conduct'. Their answers are different with COCA.

Table 1.The Test Results

\begin{tabular}{|c|c|c|c|}
\hline No. & Test questions & $\begin{array}{l}\text { The answers in } \\
\text { COCA }\end{array}$ & Results from the test \\
\hline 1 & 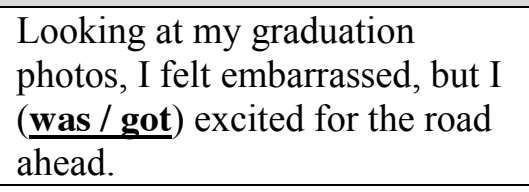 & $\mathrm{BE}$ & $\begin{array}{l}\text { Be }: 15 \text { students } \\
\text { Get }: 3 \text { students }\end{array}$ \\
\hline 2 & $\begin{array}{l}\text { First, she said she was afraid. } \\
\text { And second, she said she (was / } \\
\text { got) excited about having the } \\
\text { baby. }\end{array}$ & $\mathrm{BE}$ & $\begin{array}{l}\text { Be }: 10 \text { students } \\
\text { Get }: 8 \text { students }\end{array}$ \\
\hline 3 & $\begin{array}{l}\text { I've started actually making a } \\
\text { list of directors that I (am / get) } \\
\text { excited about and now I'm not } \\
\text { just waiting for them to have a } \\
\text { movie. }\end{array}$ & $\mathrm{BE}$ & $\begin{array}{l}\mathrm{Be}: 9 \text { students } \\
\text { Get }: 9 \text { students }\end{array}$ \\
\hline 4 & $\begin{array}{l}\text { They had been close since } \\
\text { graduate school, and she (was / } \\
\text { got) excited to get her opinion } \\
\text { of him. }\end{array}$ & $\mathrm{BE}$ & $\begin{array}{l}\text { Be }: 11 \text { students } \\
\text { Get }: 7 \text { students }\end{array}$ \\
\hline 5 & $\begin{array}{l}\text { I'm from the Carolinas and the } \\
\text { cultures are so similar. I (was / } \\
\text { got) excited to see yellow grits } \\
\text { at a local market and brought } \\
\text { some back to New York. }\end{array}$ & $\mathrm{BE}$ & $\begin{array}{l}\text { Be }: 8 \text { students } \\
\text { Get }: 10 \text { students }\end{array}$ \\
\hline 6 & $\begin{array}{l}\text { I (am / get) excited for my new } \\
\text { chapter. I now am stronger and } \\
\text { ready for what 's next. }\end{array}$ & $\mathrm{BE}$ & $\begin{array}{l}\text { Be }: 12 \text { students } \\
\text { Get }: 6 \text { students }\end{array}$ \\
\hline 7 & $\begin{array}{l}\text { I (was / got) excited to bring } \\
1960 \text { ' fashion back the cinched- } \\
\text { waist dresses and all that. }\end{array}$ & $\mathrm{BE}$ & $\begin{array}{l}\text { Be }: 6 \text { students } \\
\text { Get }: 12 \text { students }\end{array}$ \\
\hline 8 & $\begin{array}{l}\text { I (am / get) excited to } \\
\text { contribute to Black music in this } \\
\text { massive way and to eat } \\
\text { beignets. }\end{array}$ & $\mathrm{BE}$ & $\begin{array}{l}\text { Be }: 11 \text { students } \\
\text { Get }: 7 \text { students }\end{array}$ \\
\hline 9 & $\begin{array}{l}\text { People (are / get) excited by } \\
\text { bottlebrushes, for instance, but }\end{array}$ & $\mathrm{BE}$ & $\begin{array}{l}\text { Be }: 10 \text { students } \\
\text { Get }: 8 \text { students }\end{array}$ \\
\hline
\end{tabular}




\begin{tabular}{|c|c|c|c|}
\hline & $\begin{array}{l}\text { what species or cultivars } \\
\text { actually perform the best. }\end{array}$ & & \\
\hline 10 & $\begin{array}{l}\text { Now, fully informed, I (was / } \\
\text { got) excited to find it again and } \\
\text { fully study its habitat. }\end{array}$ & $\mathrm{BE}$ & $\begin{array}{l}\text { Be }: 6 \text { students } \\
\text { Get }: 12 \text { students }\end{array}$ \\
\hline 11 & $\begin{array}{l}\text { I don't know about an edge. But } \\
\text { yes, I (am / get) excited. I want } \\
\text { to be there. I want to play. }\end{array}$ & GET & $\begin{array}{l}\text { Be }: 12 \text { students } \\
\text { Get }: 6 \text { students }\end{array}$ \\
\hline 12 & $\begin{array}{l}\text { When you get-- when you (are / } \\
\text { get) excited, do you still rip off } \\
\text { your top? }\end{array}$ & GET & $\begin{array}{l}\text { Be }: 12 \text { students } \\
\text { Get }: 6 \text { students }\end{array}$ \\
\hline 13 & $\begin{array}{l}\text { Now and then I (am / get) } \\
\text { excited when I think that here, } \\
\text { somewhere, is the end to my } \\
\text { journey, }\end{array}$ & GET & $\begin{array}{l}\text { Be }: 10 \text { students } \\
\text { Get }: 8 \text { students }\end{array}$ \\
\hline 14 & $\begin{array}{l}\text { If astronomers find an Earth- } \\
\text { sized planet, everybody (is / } \\
\text { gets) excited. }\end{array}$ & GET & $\begin{array}{l}\text { Be }: 8 \text { students } \\
\text { Get }: 10 \text { students }\end{array}$ \\
\hline 15 & $\begin{array}{l}\text { OFF bipolar cells (are / get) } \\
\text { excited when light levels } \\
\text { decrease. }\end{array}$ & GET & $\begin{array}{l}\text { Be }: 13 \text { students } \\
\text { Get }: 5 \text { students }\end{array}$ \\
\hline 16 & $\begin{array}{l}\text { Every time I'm there, I (am / } \\
\text { get) excited. It's like my } \\
\text { Fenway Park, a sacred place, " } \\
\text { continued Foxworthy. }\end{array}$ & GET & $\begin{array}{l}\text { Be }: 6 \text { students } \\
\text { Get }: 12 \text { students }\end{array}$ \\
\hline 17 & $\begin{array}{l}\ldots \text { in all settings, are introducing } \\
\text { the kind of technology that } \\
\text { young people (are / get) excited } \\
\text { about: digital recording studios, } \\
\text { 3D printers, robotics and more. }\end{array}$ & GET & $\begin{array}{l}\text { Be }: 9 \text { students } \\
\text { Get }: 9 \text { students }\end{array}$ \\
\hline 18 & $\begin{array}{l}\text {... fighting, " Singh said. " I } \\
\text { don't get scared. I (am / get) } \\
\text { excited. I want to show } \\
\text { everyone the hard work I put it.. } \\
\text { " }\end{array}$ & GET & $\begin{array}{l}\text { Be }: 8 \text { students } \\
\text { Get }: 10 \text { students }\end{array}$ \\
\hline 19 & $\begin{array}{l}\text { Absolutely. I mean, we (are / } \\
\text { get) excited for every single } \\
\text { episode but particularly because } \\
\text { we have these big cliff hangers } \\
\text { in our... }\end{array}$ & GET & $\begin{array}{l}\text { Be : } 11 \text { students } \\
\text { Get : } 7 \text { students }\end{array}$ \\
\hline 20 & $\begin{array}{l}\text { There is no question he is an } \\
\text { inspiration. He (is / gets) } \\
\text { excited to the same level of } \\
\text { excitement he did the first day } \\
\text { he walked in here }\end{array}$ & GET & $\begin{array}{l}\text { Be }: 7 \text { students } \\
\text { Get }: 11 \text { students }\end{array}$ \\
\hline
\end{tabular}

Meanwhile, for question number 3 the students' answers are equal. So, we can say that there are 6 questions that have the same answers between COCA and the students' answers. On the other hand, there are 3 questions which have different answers between COCA and the students' answers.

Meanwhile, for questions number 1120, according to COCA, the answers are 'get'. Let us compare it with the answers from the students. For questions number 13, 
15,18 , and 20 , most of the students have the same answers with COCA. The answers are 'get'. On the other hand, for questions number 11,12,14,16, and 19, the answers of the students are different with the answers in COCA. Most of the students answer it with 'be'. While for question number 17 the answers are equal. So, in this case, we can say that there are 4 questions that have the same answers between COCA and the students' answers. On the other hand, there are 5 questions that have different answers between COCA and the students' answers.

\section{CONCLUSION}

From the above results, we can conclude that the students still cannot differentiate between the verb 'be' and 'get' in relation to the word 'excited'. It seems that they are more familiar with the verb 'be'. This can be seen from the first 10 questions given to the them. Out of 10 questions, 6 questions can be answered correctly by them. Meanwhile, for the second 10 questions, the students can only answer 4 questions correctly. In other words, we can say that they are not familiar with the verb 'get' when it is related to the word 'excited' Therefore, it can be said that the students still don't have good collocation knowledge. They still cannot differentiate when to use the verb 'be' or 'get' in relation to the word 'excited.'

\section{REFERENCES}

Benson, M., Benson, E., \& Ilson, R. (1997).

The BBI dictionary of English word combinations. BBI Combinatory Dictionary of English. Amsterdam: Benjamin.

Corpus. (2017). In Merriam-Webster's online dictionary. Retrieved from https://www.merriamwebster.com/dictionary/corpus

Krishnamurthy, R. (2014). Accessing all areas: Corpus analysis methods in interdiciplinary applications. Birmingham: Aston University.

Larson, M. L. (1984). Meaning-based translation: A guide to crosslanguage equivalence. Lanham: University Press of America.

Newmark, P. (1981). Approaches to translation. Oxford: Pergamon Press.
Newmark, P. (1988). A textbook of translation. London: Prentice Hall.

Sinclair, J. (1991). Corpus, concordance, collocation. Oxford: Oxford University Press.

Text corpus. (n.d.). Retrieved from https://en.wikipedia.org/wiki/Text_co rpus

What is a corpus. (2017). In Oxford dictionaries. Retrieved from https://en.oxforddictionaries.com/exp expl/what-is-a-corpus

What is corpus. (n.d.). Retrieved from http://language.worldofcomputing.net /linguistics/introduction/what-iscorpus.html 